\title{
Gravel bar inundation frequency: an important parameter for understanding riparian corridor dynamics
}

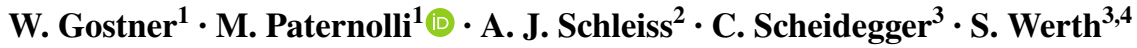

Received: 20 May 2016 / Accepted: 29 April 2017 / Published online: 5 May 2017

(C) Springer International Publishing 2017

\begin{abstract}
Riparian zones are some of the most valuable and at the same time endangered ecosystems in the world. Their progressive degradation caused by anthropogenic pressure calls for the adoption of effective, resilient restoration strategies. However, a full understanding of the complex mechanisms governing riparian ecosystems has not yet been achieved, and many assumptions are based on qualitative findings. We quantitatively investigated the habitat conditions of a key riparian plant, the German tamarisk (Myricaria germanica), using a two-dimensional hydrodynamic model that was created for a braided reach of the river Sense (Switzerland). The results demonstrate that the presence of this species in gravel bar habitats is strongly correlated with inundation frequency. The species was present on gravel bars near the main river channels, which are inundated every $4-5$ years. Where the gravel bars are frequently flooded, seedlings do not survive the hydrodynamic perturbations, whereas elsewhere, where periodic flooding does not reach, M. germanica is replaced by stronger competitors. Our study contributes to an understanding of the dynamics of riparian corridors and provides a quantitative
\end{abstract}

Electronic supplementary material The online version of this article (doi:10.1007/s00027-017-0535-2) contains supplementary material, which is available to authorized users.

\footnotetext{
M. Paternolli

m.paternolli@ipp.bz.it

1 Patscheider \& Partner Consulting Engineers Ltd., Bozen, Italy

2 Laboratory of Hydraulic Constructions, Ecole Polytechnique Fédérale de Lausanne, Lausanne, Switzerland

3 Swiss Federal Institute for Forest, Snow and Landscape Research WSL, Birmensdorf, Switzerland

4 Institute of Plant Sciences, University of Graz, Graz, Austria
}

basis for developing effective restoration plans, which may involve the optimisation of hydropower regulation programmes.

Keywords River restoration - Numerical models $\cdot$ Gravel bars $\cdot$ Flood frequency $\cdot$ Inundation $\cdot$ Myricaria germanica

\section{Introduction}

Riparian corridors are a nexus between aquatic and terrestrial environments that changes spatially and temporally due to fluvial processes driven by hydrographic events, drought periods, water quality, vegetation dynamics including invasions by non-native species, and anthropogenic influences, among many other factors, thus forming complex and highly dynamic ecosystems (Tockner and Schiemer 1998). All these aspects of riparian corridors create a landscape characterised by a highly variable mosaic of habitats of high biodiversity and productivity (Tockner and Stanford 2002; Camporeale et al. 2013).

Riparian vegetation and river processes interact with each other. On the one hand, vegetation affects several processes that control river morphology (Corenblit et al. 2007), e.g. increasing the channel roughness and altering the turbulence dynamics (Baptist et al. 2007; Nepf 2012a), or influencing sediment transport via the stabilisation of soil by roots (Pollen-Bankhead and Simon 2005, 2010). On the other hand, riparian vegetation dynamics are strongly affected by river processes. Rivers provide water, thereby enhancing soil moisture and nutrients for plant growth and facilitating hydrochoric seed dispersal (Pezeshki and Shields 2006; Gonzalez et al. 2012; Bertoldi et al. 2014). Mass processes such as the transport of river sediments not only create new depositional zones for vegetation 
colonisation but also remove vegetated areas via erosion (Pasquale et al. 2012), thereby interacting with vegetation via uprooting and burial (Friedman and Auble 1999).

Floodplain riparian zones have been identified as some of the most geomorphologically active and threatened landscapes in the world (Tockner and Stanford 2002; Sadler et al. 2004). Traditional river engineering activities directly affect the natural habitats and sediment dynamics of rivers, which in turn affect the communities of riparian plants. Along reaches of rivers with reduced sediment flow, which are common downstream of reservoirs, the natural development of new habitat patches occurs with reduced frequency. Consequently, local populations of pioneer species may decline or become locally extinct as natural plant succession progresses to later forested stages (Müller 2014). Moreover, lateral embankments (levees) and river bank protections may have negative consequences for riparian plant communities: they hinder the flooding of alluvial plains, thereby impeding seed dispersal and ultimately leading to severe reductions of species diversity in alluvial areas (Junk et al. 1989; Nilsson and Jansson 1995; Jansson et al. 2000a). It has been observed that plant dispersal is more effective in the absence of dams, and the fragmentation of riparian habitats by dams leads to changes in the spatial distribution of plant biodiversity across drainage basins (Jansson et al. 2000b; Gonzalez et al. 2010).

Therefore, in the twenty-first century, considerable emphasis is being placed on the restoration of riparian corridors as an essential means for enhancing the hydromorphological and ecological equilibrium of rivers while improving habitat diversity and variability and reducing long-term maintenance costs (FISRWG 1998; EU 2000). Riparian corridor restoration may involve the removal of river training structures to allow fluvial processes to be re-established in riparian corridors, physical restoration of channel morphologies through construction measures, removal of levees, bioengineering, grooming and enhanced planting of terrestrial species, and protection and preservation of wild areas (see for example Schropp and Bakker 1998; Roni et al. 2002; Rohde et al. 2004).

In many countries, dams add another level of complexity: they interrupt both water and longitudinal sediment connectivity, thereby altering the natural hydrologic regime (Müller 2014). Where dams are present, the restoration of riparian corridors can be promoted by altering hydropower operation programmes to ensure the release of periodic functional floods and by adopting structural measures to at least partially restore sediment connectivity (e.g., by adding sediment downstream of dams) (Robinson and Uehlinger 2003; Giller 2005; Palmer et al. 2005).

Due to the present condition of riparian corridors and the urgent need to preserve and restore them, scientific communities have expended increasing effort during the previous few decades to understand the mechanisms regulating these complex ecosystems. In the past, the main branches of the scientific community were working independently (ecologists and biologists on one side and hydraulic engineers on the other); recently, however, a more constructive and collaborative approach has been adopted. As a consequence, both semiquantitative and quantitative models were developed in attempts to link fluvial morphodynamics and riparian vegetation dynamics. The ultimate objective is to understand the key processes regulating riparian ecosystems and thereby to be able to foresee the effects of anthropogenic actions and effectively manage and restore river corridors (Camporeale et al. 2013). Solari et al. (2015) presented a thorough review of the state of the art of the modelling of riparian dynamics. What we have observed is that, despite increasing efforts to deepen our understanding of the many complex aspects of riparian zones and appropriately model them, only a few models properly take into account the many complex variables, and many simplifications have to be performed (e.g., Nepf 2012b). Two of the more successful attempts to model the interactions between hydrologic processes and vegetation are those of Camporeale and Ridolfi (2006) and Bertoldi et al. (2014); the latter study took into account morphodynamic interactions, although in a simplified way.

Riparian dynamics involve a number of factors and processes that link various aspects such as hydrology, morphology, biology, chemistry and ecology. Nevertheless, many authors regard river-driven disturbance as the main component controlling riparian vegetation processes (e.g., Poff et al. 1997; Nilsson and Svedmark 2002; Camporeale and Ridolfi 2006; Corenblit et al. 2007). In particular, flow and flood regimes control riparian vegetation colonisation and development (Bornette et al. 2008). Ye et al. (2013) built a model to predict which hydrological component is dominant in affecting vegetation cover in riparian zones, and they concluded that floods are the main regulating process. Biological and chemical processes exert secondary control on species presence and abundance (Gurnell et al. 2012). Hydrodynamic disturbances are at a maximum within and near the channel and decrease farther from the river, where competition between species becomes dominant (Corenblit et al. 2007). In riparian environments, successional dynamics are periodically interrupted by fluvial disturbances, leading to a mosaic of patches at various successional stages (Camporeale et al. 2013). This process is characteristic of natural fluvial ecosystems and has been called the "shifting habitat mosaic" (Pringle et al. 1988; Stanford et al. 2005). Fundamental are the "flood pulse" (Junk et al. 1989) and the "flow pulse" (Tockner et al. 2000) concepts. They both focus on the interconnections between rivers and surrounding floodplains, which are considered a unique dynamic system where hydrological and ecological 
processes actively interact. While Junk et al. (1989) consider flood pulse as the driving force in determining riverfloodplain systems' equilibrium, Tockner et al. (2000) also stress the ecological importance of expansion-contraction events below bankfull flooding (flow pulses). Moreover, fluvial hydrodynamics play an important role during all stages of plant life from seed dispersal to colonisation, recruitment, growth, succession and finally mortality (Crouzy et al. 2013; Egger et al. 2013; Solari et al. 2015).

The colonisation success of riparian species that populate point bars, central bars and other mid-channel depositional features between large hydrographic events is directly dependent on the frequency and duration of the events (Tanaka and Yagisawa 2012; De Silva et al. 2013). Nevertheless, quantitative findings regarding the frequency and duration of inundation of floodplains and mid-channel depositional features and their effects on riparian species are still scarce (De Silva et al. 2013). Some qualitative findings have resulted from recent monitoring programmes following several restoration projects (Egger et al. 2010; Lener et al. 2013). The aim of this study was to test how the frequency of floods in an alpine braided river reach affects the colonisation of a native early-succession riparian species (Myricaria germanica). We chose a study site (river Sense near Plaffeien, Switzerland) with a pristine morphologic configuration, an unaltered hydrologic and sedimentologic regime, an absence of artificial regulation and stabilisation works and a lack of biologic stress factors, which combine to create a potential habitat for the dispersal, establishment and growth of $M$. germanica. The analysis of the interactions between the flow field and vegetation were performed by means of a hydrodynamic numerical model.

\section{Methods}

\section{Study site}

The river Sense is a fourth-order watercourse within a $432 \mathrm{~km}^{2}$ drainage basin located in the cantons of Fribourg and Bern, Switzerland (Fig. 1). The drainage basin contains one of the last unregulated rivers in Switzerland, where hydrographic events are driven solely by snowmelt and precipitation and not by any hydropower projects or major flow diversion works. Downstream from the confluence of several headwater streams (near Plaffeien-Fig. 1), the main stem of the river flows a distance of $35 \mathrm{~km}$ before its confluence with the river Saane (Gostner 2012).

We investigated the inundation frequency of a braided reach near Plaffeien (Fig. 1), where Myricaria germanica (German tamarisk; Tamaricaceae, Caryophyllales) was observed growing on several gravel bars. In the braided parafluvial zones of the river, which are the areas of the

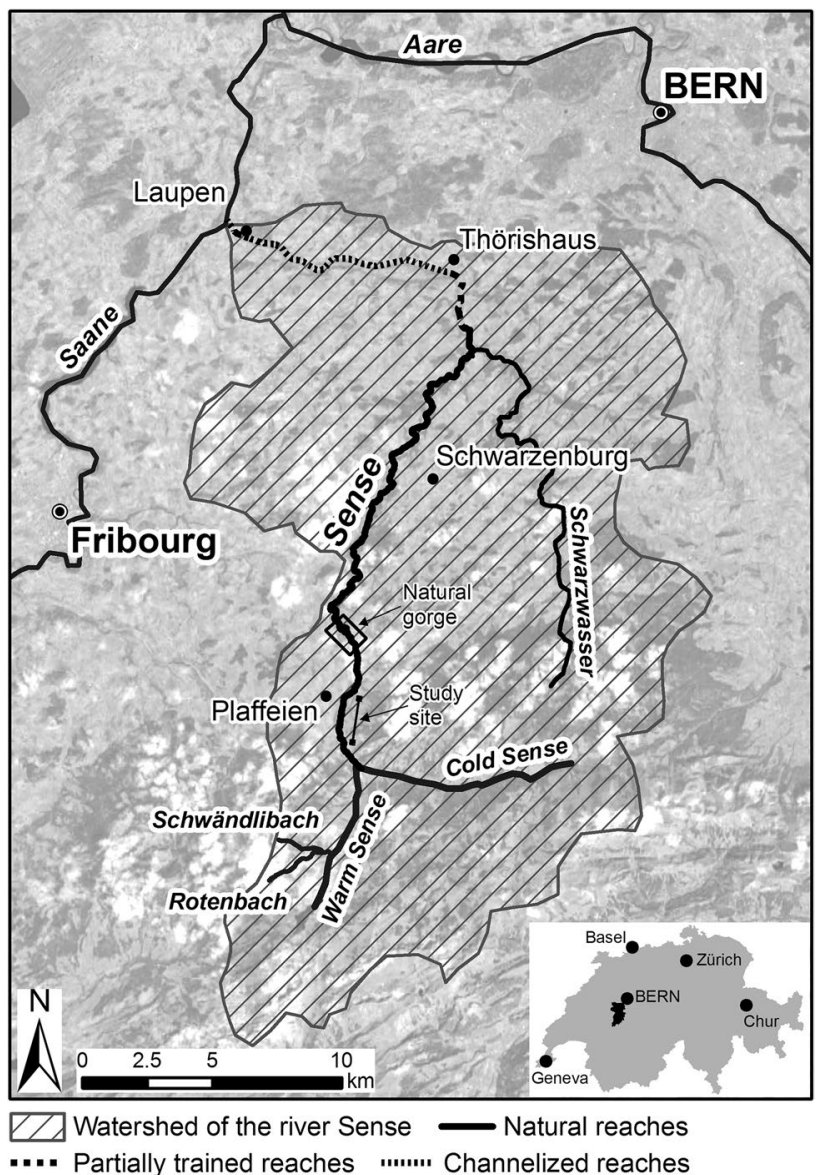

Fig. 1 The river Sense site location map showing natural and trained reaches. A rectangular box highlights the natural gorge downstream of Plaffeien

bankfull channel that are affected annually to some extent by scour and deposition (Stanford et al. 2005), the morphology is dominated by numerous channel avulsions and mid- and side-channel bars. The result is a mosaic of habitats (Lorang and Hauer 2006) with frequent bank retreats and tree losses and abundant woody debris, emergent vegetation and successional terrestrial species growing on depositional forms characterized by different elevations.

The study site is located at an altitude of ca. $800 \mathrm{~m}$ a.s.l., it is approximately $2 \mathrm{~km}$ long (Fig. 2), with an average bankfull width of $150 \mathrm{~m}$, an average valley width of ca. $290 \mathrm{~m}$ and a slope of $2 \%$; the parafluvial zones measure a total of approximately 25 hectares. The upstream drainage basin measures $118 \mathrm{~km}^{2}$ and it is hydrologically characterised by a transitional snow regime. From a geological point of view, it is mainly composed of sedimentary rocks, with a major component of limestone in the upper part and of marl schist and calcareous phyllite at the medium and lower heights, while in Plaffeien alluvial deposits prevail. 


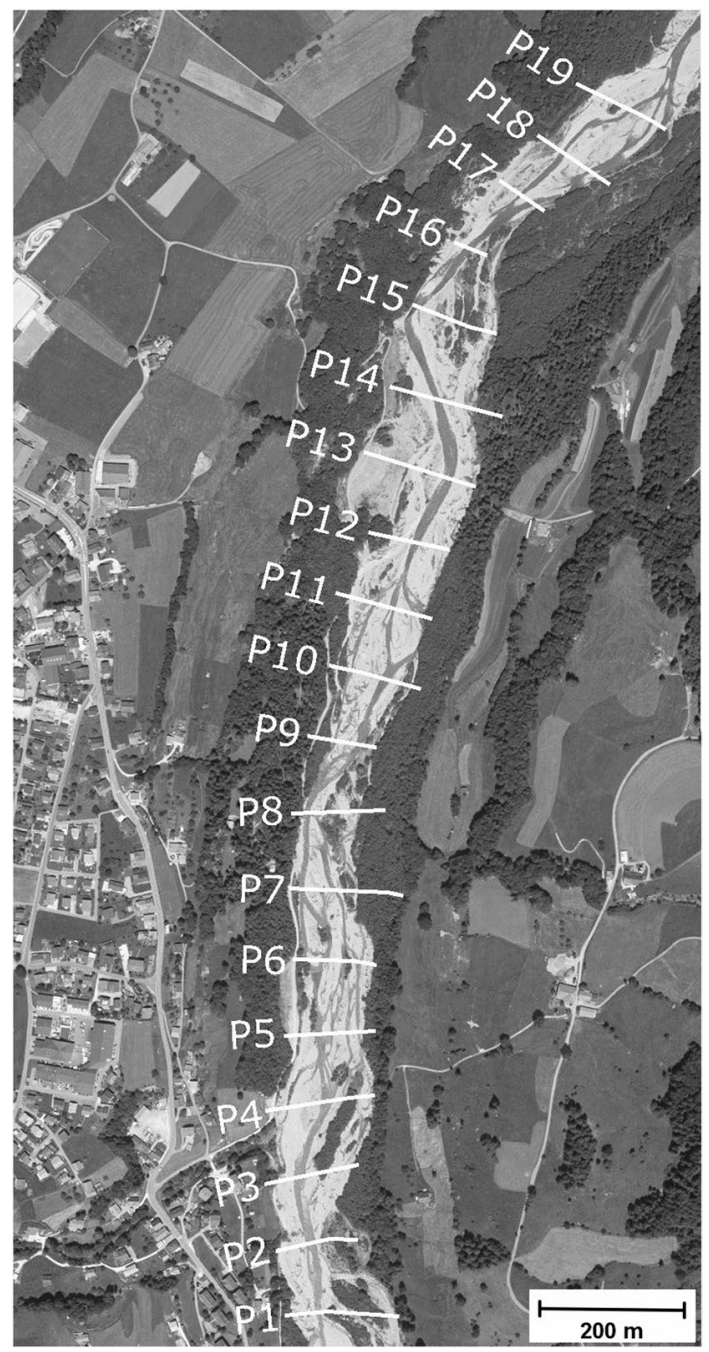

Fig. 2 The study site near Plaffeien and cross section locations

\section{Study species}

The riparian shrub Myricaria germanica is a characteristic species of the pioneer vegetation of natural rivers and is thus considered an indicator of high biotic integrity of rivers. It has a wide distribution, being present in Europe, Anatolia (Turkey), Armenia, Russia, Iran, Afghanistan, and New Zealand, where it is known as an invasive species. In Europe, it extends between the Pyrenees, Scandinavia, Alps, Central Apennines and the Illyricum mountains (Michielon and Sitzia 2010). In particular, in Central Europe this species is often present along large, braided rivers with natural or near-natural habitat dynamics (Werth and Scheidegger 2014). Its distribution is determined by a complex interaction between geological and geomorphological characteristics of the drainage basin and of the river reach, flow regime and bioclimatic conditions. Kudrnovsky (2013) carried out an extensive survey of the distribution of M. germanica in the European Eastern Alps, identifying three main suitable habitat variants: $M$. germanica was found as open-structured stocks on sandy sites at higher altitudes (above $1300 \mathrm{~m}$ ), on top of sandy gravel bars close to the main river channel, or along flood lines or in slight depressions situated at some distance from the main river channel.

The shrub is pollinated by insects such as bees and flies, but selfing is also possible. Based on observations gathered during laboratory experiments, Benkler and Bregy (2010) found that its seeds germinate well on a matrix of sand and silt, characterised by good capillarity and a favourable moisture content. The first stage of growth (approximately the first year of life) is largely dependent on the nutritive contribution from the shoots; therefore, the main limiting factor for survival during this stage is the moisture in the growth substrate. This period of life is characterised by expansion of the roots, which is a slow process during which the plants are particularly sensitive to hydro-morphological dynamics. In locations with a high inundation frequency, the seeds and seedlings tend to be washed away. Moreover, the seedlings are easily outcompeted by stronger competitors such as willows (Salix), which are more drought tolerant than M. germanica. Starting in the second year of its life, M. germanica's growth rate accelerates, and the plant becomes stronger and more resistant to mechanical disturbances from the flow regime. The plant possesses a notable tolerance to periodic floods and can survive being inundated and buried under sediment. These characteristics make it a strong competitor against almost all of its rivals, which are less resistant to morphodynamic fluctuations (Lener et al. 2013). When these mechanical disturbances are lacking, M. germanica is outcompeted and replaced by species belonging to later stages of succession, such as Salix bushes (Egger et al. 2010).

Myricaria germanica has faced a severe decline during the previous several decades due to human impacts on river ecosystems, such as the straightening of river channels and the creation of lateral embankments, which have caused degradation and loss of habitats (Endress 1975; Bill et al. 1997). In Austria, M. germanica went extinct in most of the rivers, due to substantial regulation works, and today it is limited to the natural reaches of Lech and Isel rivers (Kudrnovsky and Stöhr 2013). Furthermore, populations of the species become genetically isolated if they are separated by dams and reservoirs (Werth et al. 2014), even though the species reproduces via small seeds that are well dispersed by air currents and water (Lanz and Stecher 2009). 


\section{Field data collection}

Nineteen cross sections (Fig. 2) and a longitudinal thalweg profile along the channel were surveyed using a first-order GPS base and rover station (Topcon Hiper Pro). The transects were spaced at intervals of approximately $100 \mathrm{~m}$ perpendicular to the mean channel flow direction to characterise the geomorphic features (Simonson et al. 1994), which included the thalweg, the tops and bottoms of the banks, the bankfull stage, terrace elevations and any additional breaks in the topography. The limits of islands and depositional features were surveyed in addition to the maximum elevation of each feature and the locations of woody debris piles.

The locations of the terrestrial species of interest were acquired from a parallel biological inventory using a handheld GPS. As a result, the spatial distribution of M. germanica was represented by polygonal areas on the gravel bars where the plant was identified.

The stream discharge velocities within each cross section were obtained using the six-tenths-depth method (Turnipseed and Sauer 2010) using a Sontek Flow Tracker ${ }^{\circledR}$ acoustic Doppler velocity metre.

Surface material sizes and their distributions were characterised using the Wolman pebble count method (Wolman 1954) along each cross section within the bankfull limits of the channel. This approach consisted of randomly sampling a grain exposed on the ground surface at intervals of approximately $1 \mathrm{~m}$ along a transect and measuring the grain's intermediate axis. Then, grain size distribution plots of the surface layer were generated for each cross section, and the median particle diameters from log-normal distribution plots were used to determine the median grain size $\left(D_{50}\right)$. In addition to this surface layer analysis, the global composition of the gravel bars material (surface and subsurface layers) was investigated in the upper part of the reach between transects P2 and P3 (Fig. 2) by means of two volumetric samplings. Each sample measured approximately $1 \mathrm{~m}^{2}$ horizontally and was approximately $25 \mathrm{~cm}$ deep. These samples were sieved and, after plotting their grain size distributions, the $\mathrm{D}_{50}$ was determined.

\section{Hydrology}

A hydrometric gauge station was not available at the study site. Therefore, a duration curve was defined based on a Swiss regional model of mean flow (Pfaundler and Zappa 2006), which is based on ordinal datasets dating from 1981 to 2000 and on available discharge records at gauge stations in the region. Two gauge stations are located upstream (approximately $7 \mathrm{~km}$ ) of the study site on two tributaries (Rotenbach and Schwändlibach), one gauge is located $15 \mathrm{~km}$ downstream at Thörishaus, and a fourth gauge is located on the river Saane at Laupen immediately downstream of the confluence with the river Sense (Fig. 1).

A flow duration curve based on the daily mean flow time series recorded between 1993 and 2008 at the Thörishaus gauge station was extrapolated for discharges of less than an annual flood. Using the regional model, the mean annual specific flow was calculated for the river Sense at Thörishaus and for the study site. Therefore a correction factor $(f)$, defined as the ratio between the mean annual specific flow for the drainage basin at the study site $\left(\bar{q}_{P f}\right)$ and the gauge station at Thörishaus $\left(\bar{q}_{T h}\right)$, was calculated:

$f=\frac{\bar{q}_{P f}}{\bar{q}_{T h}}=1.4$

This scaling factor was validated by comparing the discharge calculated from the velocities measured in the field with the discharge recorded at the Thörishaus gauge station on the same day. On the day of measurement, the average daily discharge at Thörishaus was $4.8 \mathrm{~m}^{3} \mathrm{~s}^{-1}$. The scale factor derived from the regional model yields a predicted discharge at Plaffeien of $2.2 \mathrm{~m}^{3} \mathrm{~s}^{-1}$, whereas a discharge of $2.4 \mathrm{~m}^{3} \mathrm{~s}^{-1}$ was calculated based on the velocities measured in the field. Given the small difference between the observed average daily discharge and that predicted using the regional model, we assumed that the correction factor of 1.4 was sufficiently reliable for use in the study. The flow duration curve at the study site $\left(Q_{P f}\right)$ was calculated by multiplying the discharges at the Thörishaus gauge station $\left(Q_{T h}\right)$ with the correction factor $(f)$ and the ratio between the drainage basin areas upstream of the study site $\left(A_{P f}\right)$ and the Thörishaus gauge station $\left(A_{T h}\right)$.

$Q_{P f}=Q_{T h} \cdot f \cdot \frac{A_{P f}}{A_{T h}}$

Discharges corresponding to return periods longer than 1 year were extrapolated from the official peak flow values available at the four gauge stations. Specifically, regression curves relating specific flow to drainage basin area were derived for return periods ranging from 2 to 50 years, thereby permitting us to evaluate the peak discharges at Plaffeien (Table 1).

\section{Numerical model development}

The numerical model FLUMEN (FLUvial Modelling ENgine) was used to investigate the spatial distribution and inundation frequency of depositional features at the study site. FLUMEN is a two-dimensional surface-water model that can be used to investigate the hydraulic behaviour of rivers and coastal waters in a variety of discharge conditions. The programme solves the depth-averaged 
Table 1 Return frequencies and extrapolated discharges $(\mathrm{Q})$ at the study site

\begin{tabular}{llll}
\hline $\begin{array}{l}\text { Return period } \\
\text { years }\end{array}$ & $\begin{array}{l}\mathrm{Q} \\
\mathrm{m}^{3} \mathrm{~s}^{-1}\end{array}$ & $\begin{array}{l}\text { Return period } \\
\text { years }\end{array}$ & $\begin{array}{l}\mathrm{Q} \\
\mathrm{m}^{3} \mathrm{~s}^{-1}\end{array}$ \\
\hline 1 & 45 & 7 & 195 \\
1.3 & 75 & 10 & 208 \\
2 & 124 & 30 & 266 \\
5 & 172 & 50 & 296 \\
\hline
\end{tabular}

shallow-water flow equations in a cell-centred unstructured mesh that allows for wet and dry domains, sub- and supercritical flow conditions, and specification of variable streambed topography. The model is based on the finite-volume approach and uses the first-order explicit Euler method for time discretisation (Beffa 2004).

The modelling domain was defined based on the topographical survey within the floodplain (Fig. 2), and data extracted from a digital terrain model were used for the surrounding area. The surface grain size distribution curves indicate a median particle diameter $\left(D_{50}\right)$ of $53 \mathrm{~mm}$ within the reach. Using the Strickler approach (Strickler 1923), a corresponding average Manning's roughness value $(n)$ of $0.03 \mathrm{~m}^{-1 / 3} \mathrm{~s}$ was calculated (Eq. 3) and was adopted for the bankfull channel in the zones devoid of mature vegetation.

$n=\frac{D_{50}^{1 / 6}}{21.1}$

Floodplain roughness beyond the limits of the bankfull channel and in mature tree stands on islands (delineated during the biological inventory) was estimated to be in the range of $0.05<n \leq 0.10 \mathrm{~m}^{-1 / 3} \mathrm{~s}$ and was associated with the density and stem diameter of vegetation communities as suggested by Chow (1959). Apart from the increase in the roughness coefficient, the presence of vegetation was not used directly in the numerical model. Instead, its correlation with inundated areas was investigated during post-processing by means of a GIS analysis based on the coverage mapping performed during the field campaigns. The river bed was assumed to be stable.

\section{Calibration of the model}

To calibrate the numerical model, we ran a simulation with the discharge recorded during the field day $\left(2.4 \mathrm{~m}^{3} \mathrm{~s}^{-1}\right)$. Due to the highly variable bed topography at the site, both in the longitudinal and transverse directions, we decided to compare the model results with the measured data based on the water elevation instead of the water depth. Along each transect, a unique average water elevation was considered. This value was extracted from the survey data and from

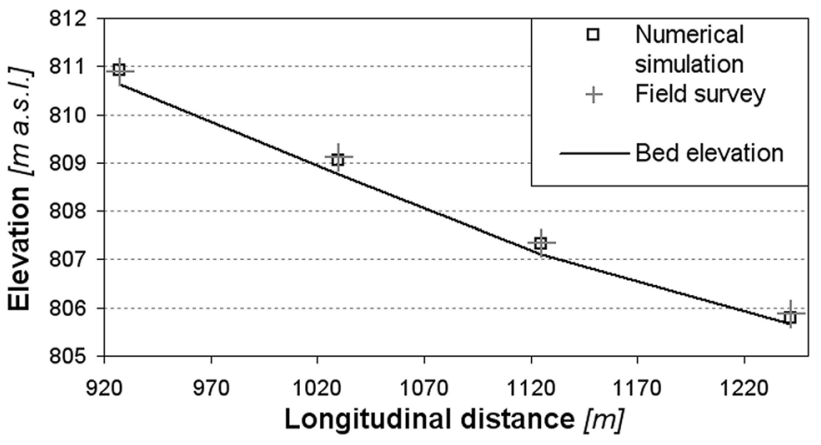

Fig. 3 Comparison between measured and simulated water elevations during a discharge of $2.4 \mathrm{~m}^{3} \mathrm{~s}^{-1}\left(\mathrm{R}^{2}=0.99, \mathrm{P}<0.0001\right)$

the results of the numerical model in each computational cell along each cross section. These water elevations were compared only at cross sections where the total flow was confined to a single channel rather than where there were multiple flow paths. These locations of single flow paths were selected because they offered greater flow depths and decreased the cross sectional variations, thereby leading to better comparisons between observed and predicted water elevations. The most upstream and downstream cross sections were also eliminated from the comparison due to boundary condition limitations in the numerical model. Figure 3 shows the geodetic elevations of the thalweg profile (bed elevation) and of the calculated and measured water level along a segment of the reach. The analysis yielded a satisfactory and statistically significant correlation between the measured and calculated values of flow elevation $\left(\mathrm{R}^{2}=0.99, \mathrm{P}<0.0001\right)$.

The bankfull discharge frequency was also calculated as a qualitative metric to evaluate the accuracy of the model. Kellerhals et al. (1972) observed that the return frequency of bankfull discharge in braided rivers in western Canada ranged between 2 and 7 years. In our study, a series of simulations with various discharges were conducted to determine the discharge (and associated return period) that yielded the bankfull water elevation that best correlated with the bankfull height observed in the field. A discharge of $172 \mathrm{~m}^{3} \mathrm{~s}^{-1}$ (corresponding to a 5-year return period) best correlated with the observed bankfull elevation (Fig. 4, $\left.\mathrm{R}^{2}=0.99, \mathrm{P}<0.0001\right)$.

\section{Parafluvial zone and bar inundation frequency}

Based on the two-dimensional simulation of discharges ranging between low-flow conditions and the 10-year discharge, i.e., between 2 and $208 \mathrm{~m}^{3} \mathrm{~s}^{-1}$, we performed both at a larger and at a smaller scale analysis. Initially, the entire river reach was investigated to analyse the progressive parafluvial zone inundation with increasing discharge 


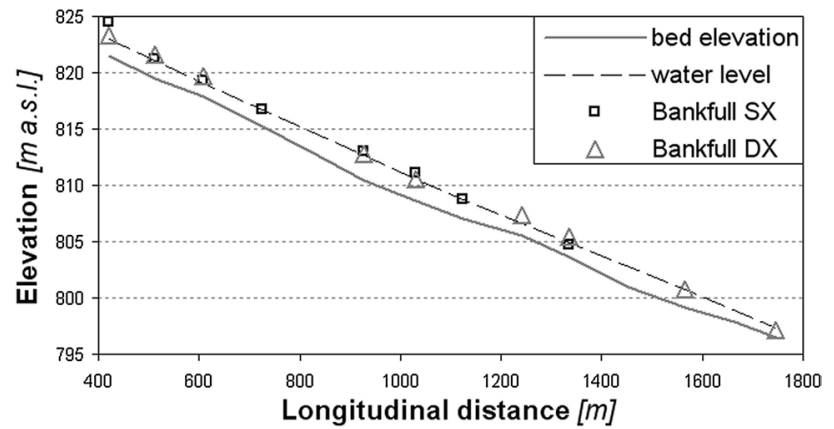

Fig. 4 Comparison between bankfull height and water level during a discharge of $172 \mathrm{~m}^{3} \mathrm{~s}^{-1}$ (HQ5). Bankfull SX and bankfull DX are the left and right bankfull heights, respectively $\left(\mathrm{R}^{2}=0.99, \mathrm{P}<0.0001\right)$

as it relates to various annual durations of exposure. Moreover, relative percentages of inundated (wet) and exposed (dry) parafluvial zones were calculated for a series of discharge simulations related to specific frequency return periods. The final objective was to carry out a first investigation on the presence of various types of depositional forms (characterized by different vegetation covers) and their correlations with discharge magnitudes and frequencies.

As a second step, a small reach of interest $600 \mathrm{~m}$ long located between cross sections P3 and P9 (Fig. 2) was analysed in greater detail. This reach segment is of particular interest in that it presents, in a relatively limited area (about 4 hectares) several gravel bar deposits at various elevations. In addition, one group of bars supports $M$. germanica, a second group supports stands of grey alder (Alnus incana), and a third group supports neither species. Rather than evaluating the areal percentage of parafluvial inundation in relation to a pre-determined discharge frequency, here we investigated the discharge in relation to the water surface elevation when the surfaces of specific gravel bars and islands became inundated. For this purpose, we checked the presence of some particular discharges responsible of substantial variations in the inundated area, by running a series of simulations and analysing the relationship between the change in exposed parafluvial area $(d A)$ and change in discharge $(d Q)$ as a function of discharge. Indeed, the presence of inflection points in this function corresponds to threshold discharges where significant changes in exposed surface area occur. The final target of this analysis was to investigate the presence of particular discharges with known return frequencies and their correlation with the successful colonisation of certain gravel bar sites by $M$. germanica.

\section{Threshold for material mobilisation}

In addition to the analysis of the frequency of inundation of the gravel bars where $M$. germanica grows, another important issue to evaluate was the threshold for the mobilisation of the bar deposits.

For the analysis of grain mobilisation conditions, the Shields parameter was used (Armanini 2005):

$\theta=\frac{R_{h} \cdot s}{\Delta \cdot d}$

where $\theta(-)$ is the Shields non-dimensional shear stress, $R_{h}(\mathrm{~m})$ is the hydraulic radius (here approximated with the hydraulic depth of the computational cell $h), s(-)$ is the bed slope, and $d(\mathrm{~m})$ is the characteristic diameter of the material (assumed to equal the $d_{50}$ of the grain size distribution). $\Delta(-)$ represents the relative density of the grains, defined as the ratio $\left(\rho_{s}-\rho\right) / \rho$, where $\rho$ and $\rho_{s}$ are the density of water and the sediment, respectively $\left(\mathrm{kg} \mathrm{m}^{-3}\right)$.

The threshold value of the Shields parameter $\theta_{c}$, above which the mobilisation of grains occurs, can be calculated using the expression proposed by Brownlie (1981):

$\theta_{c}=0.22 D_{*}^{-1}+0.06 e^{-17.77 D_{*}^{-1}}$

The term $D_{*}(-)$ is the non-dimensional characteristic diameter of the material and can be calculated using the following formula (Yalin 1972):

$D_{*}=d\left(\frac{g \cdot \Delta}{v^{2}}\right)^{1 / 3}$

where $g\left(\mathrm{~m} \mathrm{~s}^{-2}\right)$ is the gravitational acceleration and $v$ $\left(\mathrm{m}^{2} \mathrm{~s}^{-1}\right)$ is the kinematic viscosity of water.

The threshold for the initiation of movement is reached when $\theta$ equals $\theta_{c}$. Thus, by equating Eq. 4 and Eq. 5, the flow depth corresponding to the beginning of mobilisation of the bed material can be calculated (Eq. 7). By analysing the results of several hydraulic simulations corresponding to various flow discharges, the return period of the flood responsible for initiating transport of the gravel bar material was investigated.

$h \cong R_{h}=\frac{\Delta \cdot d \cdot\left(0.22 D_{*}^{-1}+0.06 e^{-17.77 D_{*}^{-1}}\right)}{s}$

\section{Results}

\section{Overall study site}

The spatial distribution of inundation of the reach resulting from six primary simulations is depicted in Fig. 5. These results indicate that with increasing discharge, an increasing proportion of the river bed is inundated, thereby creating more isolated dry regions (pseudo islands) as the flow increases to approximately $45 \mathrm{~m}^{3} \mathrm{~s}^{-1}$ (which corresponds to 
Fig. 5 The parafluvial zone inundation corresponding to various flow regimes. The dashed rectangle indicates the reach segment shown in Fig. 9
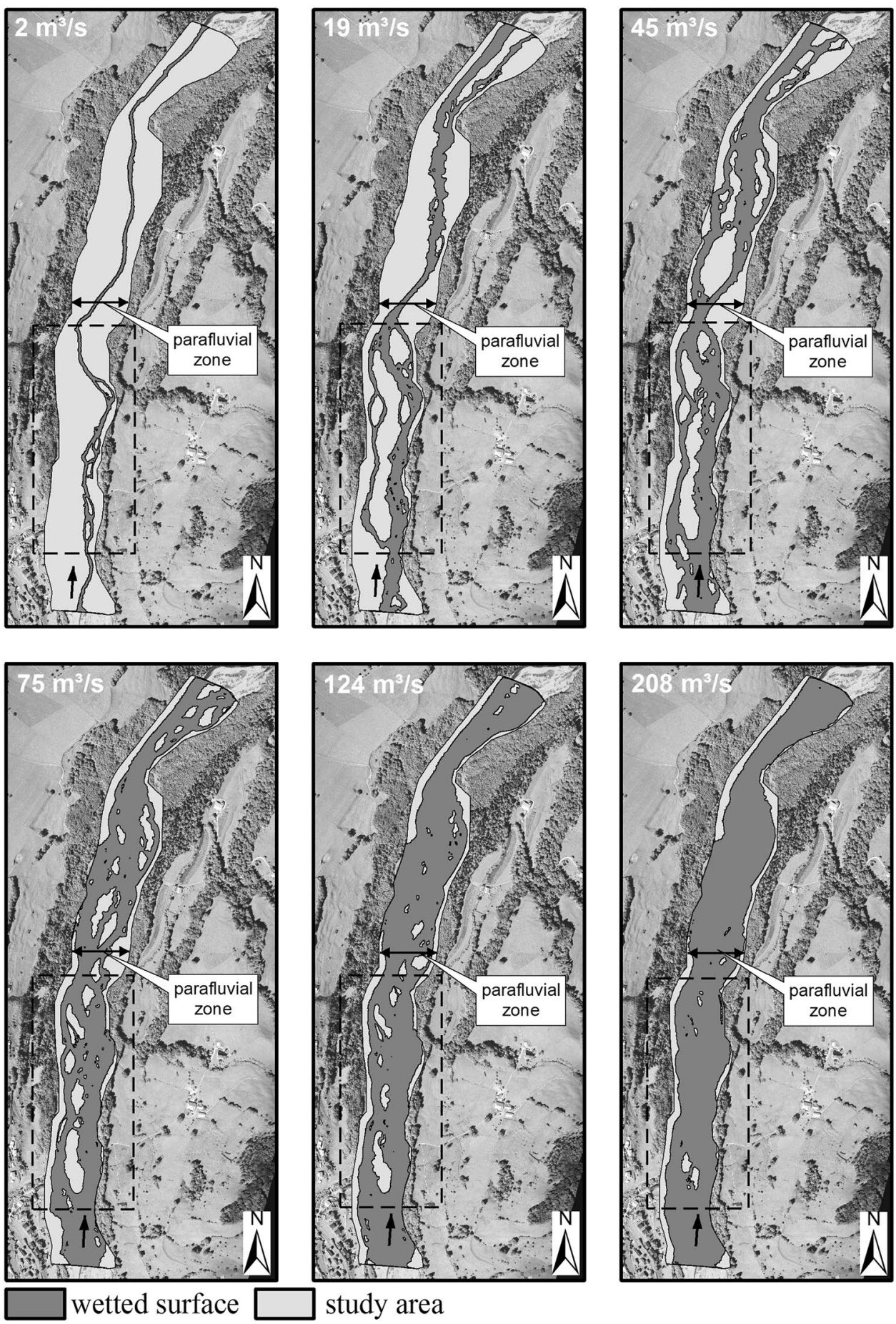

study area

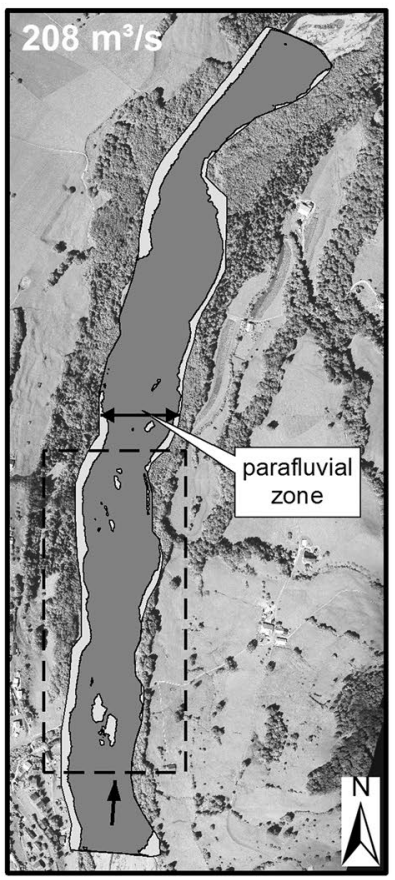

a 1-year discharge return frequency), followed by shrinkage of the isolated regions until the majority of the channel is inundated at a flow of $208 \mathrm{~m}^{3} \mathrm{~s}^{-1}$ (10-year flood). The remaining dry regions correspond to islands identified from the field investigations where mature, well-established tree stands exist.

The relationship between the submerged (wet) surface area of the reach and the annual duration of exposure
(Fig. 6) indicates that at low-flow conditions $\left(2 \mathrm{~m}^{3} \mathrm{~s}^{-1}\right)$, $20,000 \mathrm{~m}^{2}$ of the study area is inundated $(9 \%$ of the total parafluvial zone) and that the inundation trend follows a logarithmic profile with decreasing annual duration (increasing discharge). During the flood with a 1-year return period $\left(45 \mathrm{~m}^{3} \mathrm{~s}^{-1}\right)$, approximately $140,000 \mathrm{~m}^{2}$ of the reach is inundated, which corresponds to $56 \%$ of the total parafluvial zone. Furthermore, only $10 \%$ of the total 


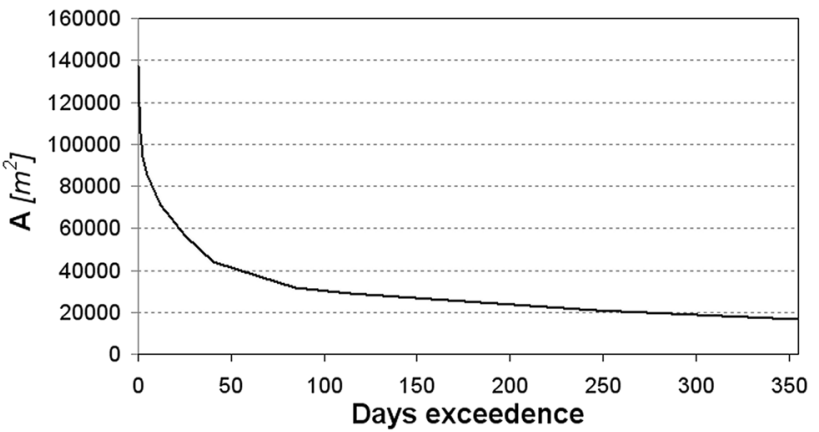

Fig. 6 The area of wetted parafluvial zone versus annual duration

parafluvial zone is inundated during more than half of an average discharge year, and $20 \%$ of the parafluvial zone is inundated for 25 days/year or less (the study site flow duration curve is reported in Online Resource 1). The main hydraulic parameters also indicate that the fluctuations in water depth and flow velocity are low during most of the year and become more consistent during floods exceeding the 1-year return period.

The relationship between relative wet/dry area percentages and discharge return frequency (Fig. 7) indicates that a rapid increase in inundation area occurs within the parafluvial zone with flows of up to approximately the 2-year return period (approximately $85 \%$ wetted surface area). With increasing discharge return frequencies, the relative areal increase in inundation significantly decreases. The rapid increase in parafluvial zone inundation relates to the range of discharges that are submerging all the mid-channel and side channel bars. During discharges exceeding the 2-year return period, only the highest islands remain dry; these features correspond to the locations of well-developed characteristic floodplain vegetation. A small portion of the parafluvial zone remains dry during the 30-year return period flows. This area corresponds to an abandoned island that has persisted over several decades.

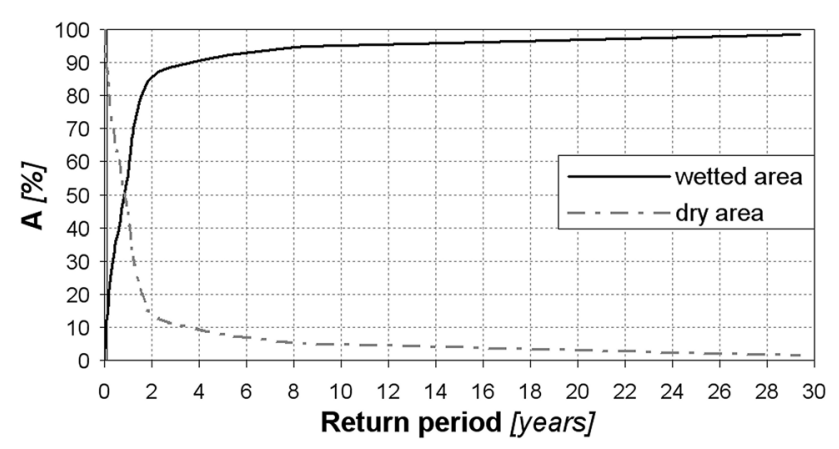

Fig. 7 Trend of wetted and dry areas across the floodplain corresponding to floods of various return periods

\section{Special area of interest}

While analysing the particular area of interest between cross sections P3 and P9 (see Figs. 2, 5), a relationship was derived between the percentage of dry parafluvial zone and the discharge and between the discharge and the ratio of the change in exposed parafluvial area to the change in discharge, i.e., $d A / d Q$ (Fig. 8). The curve shows the presence of five inflection points, namely local maxima in the $d A / d Q$ ratio. The five corresponding threshold discharges, i.e. 10, $19,32,75$, and $195 \mathrm{~m}^{3} \mathrm{~s}^{-1}$, are related to water surface elevations where there are significant changes in parafluvial inundation (Fig. 8). Figure 9 shows the distribution of dry and wet zones in the reach segment associated with the threshold flow conditions shown in Fig. 8. An additional case corresponding to $8.5 \mathrm{~m}^{3} \mathrm{~s}^{-1}$ is also depicted: this case corresponds to the lowest discharge when two flowing channels begin to form in the parafluvial zone.

A first analysis of the simulations results in the subreach of interest confirms the trend observed in the overall study site: a progressive increase in discharge from 10 to $75 \mathrm{~m}^{3} \mathrm{~s}^{-1}$ involves a substantial increase in parafluvial zone inundation. In particular, in correspondence of the threshold discharges highlighted above, the primary dry zone is avulsed by the development of a number of secondary channels, with the consequent formation of several islands (Fig. 9). A discharge of $75 \mathrm{~m}^{3} \mathrm{~s}^{-1}$ corresponds to a return period of approximately 1.3 years. At discharges exceeding $75 \mathrm{~m}^{3} \mathrm{~s}^{-1}$, no significant change in inundated surface area occurs until a discharge of $195 \mathrm{~m}^{3} \mathrm{~s}^{-1}$ (7-year return period) is reached; this discharge exceeds the bankfull stage (discharge of $172 \mathrm{~m}^{3} \mathrm{~s}^{-1}$ and a 5-year return period).

Focusing on the spatial analysis of the inundated surfaces in relation to the presence of the various types of depositional forms mapped during the field surveys, at a flow of $75 \mathrm{~m}^{3} \mathrm{~s}^{-1}$ the majority of the gravel bars devoid of vegetation (which are at lower elevations) are submerged, whereas the higher bars populated by $M$. germanica are

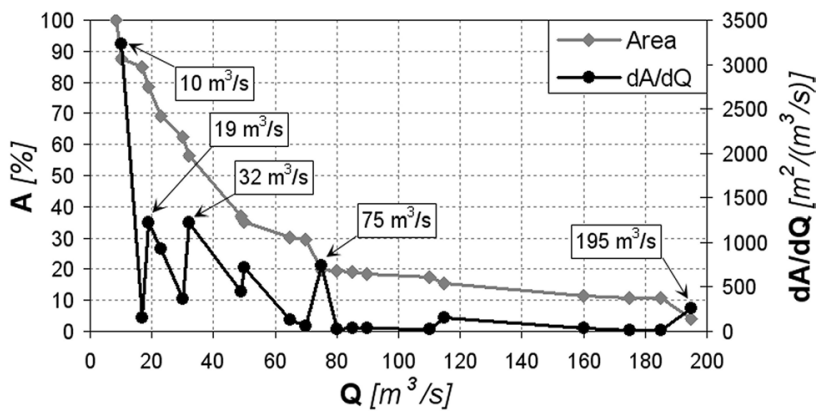

Fig. 8 Decrease in size of continuously dry gravel bar due to increasing discharge (grey line) and variation in $\mathrm{dA} / \mathrm{dQ}$ with discharge (black line) 
Fig. 9 Wetted and dry areas with varying discharge in the reach segment. The dashed areas depict the continuously dry surfaces, and the darker solid shading depicts the inundated areas
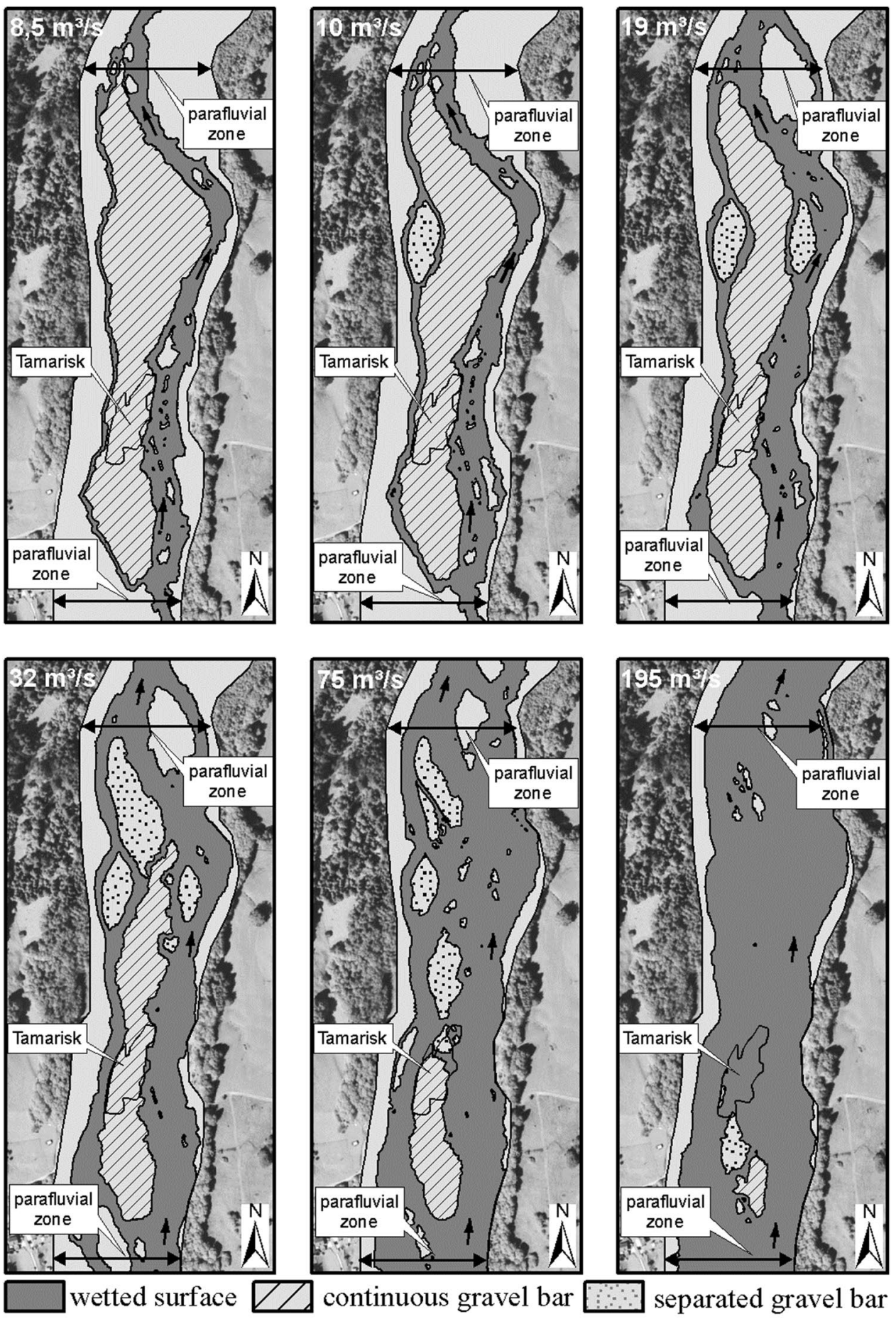

still above the water surface. At discharges corresponding to the 4- and 5-year return frequencies (almost bankfull discharge), the areas colonised by $M$. germanica are completely inundated. During a discharge of $195 \mathrm{~m}^{3} \mathrm{~s}^{-1}$ (7-year return period) also the adjacent floodplains are inundated, with the exception of an island that coincides with a low terrace with a mature tree stand. These results clearly show the notable correlation between bar coverage types (no vegetation, $M$. germanica, and mature tree stands) and bar inundation frequency, which is in turn strongly dependent on the elevation of the various depositional forms.

The analysis of the threshold for mobilisation of the bar material where $M$. germanica grows first requires the determination of the particles characteristic diameters. The $d_{50}$ of the surface material resulting from the pebble counts performed on the bars populated by $M$. germanica is equal 
to $73 \mathrm{~mm}$ (grain size distribution plots at each cross section are reported in Online Resource 2). From the volumetric analysis the $d_{50}$ of the subsurface material amounts to $66 \mathrm{~mm}$ (grain size distribution plots are shown in Online Resource 3). Therefore, once the surface layer is mobilised, the entire bar will be progressively eroded. Following the procedure described earlier and assuming a sediment specific gravity of 1.65 , a non-dimensional shear stress of 0.06 and a bed slope of $2.1 \%$ along the reach segment, the critical flow depth corresponding to a diameter of $73 \mathrm{~mm}$ is $0.33 \mathrm{~m}$. This depth corresponds to a flood with return period of approximately 7 years $\left(195 \mathrm{~m}^{3} \mathrm{~s}^{-1}\right)$. Therefore, the gravel bars populated by $M$. germanica are inundated during floods with a return period of 4-5 years, whereas mobilisation of the bar material requires a flood with return period of at least 7 years.

\section{Discussion}

\section{Actual findings of the research}

\section{Characterising the hydro-morphological configuration at natural sites using numerical models}

Among the species populating riparian corridors, M. germanica can be regarded as an indicator of the ecological integrity of alpine streams (Egger et al. 2010) in that it is particularly sensitive to both hydrologic and morphologic dynamics among other factors. The main features distinguishing a pristine river reach from a regulated one are the greater hydro-morphological variety of the former and the occurrence of typical riparian pioneer species.

The reach investigated in this study exhibits all the characteristics typical of a natural stream. The highly variable bed morphology implies a notable diversity of aspects linked to the flow regime, particularly, the highly variable wetted surface. In addition to the main channel, several secondary channels become active with increasing discharge (Figs. 5, 9), and depositional features at different elevations are progressively inundated in proportion to the flow rate. The results confirm the validity of the "flow pulses" concept (Tockner et al. 2000), according to which distinct variations of floodplains wetted surface occur not only at flood pulses, but also for events below bankfull.

The numerical modelling indicates that there is a notable spatial variation across the computational domain in terms of both water depth and flow velocity. The mesohabitats in this braided reach (e.g., pools, riffles, and runs) are characterised by different values of these two parameters, showing a significant variation typical of natural streams (e.g., Hauer et al. 2012). In addition to the spatial variability, a distinct peculiarity of morphologically heterogeneous reaches is the temporal variation in the hydraulic parameters (Gostner et al. 2013). The simulations of this study and numerical modelling of the same reach by other researchers (Gostner et al. 2013) indicate that during ordinary discharges (a flow with a return period of less than approximately 1 year), there are only slight variations in the water depth and flow velocity despite a significant increase in the wetted surface area. Only floods greater than the 1-year return period, when a consistent portion of the parafluvial zone is wetted, induce notable variations in the hydraulic parameters with increasing discharge. The marked habitat diversity and dynamism at the natural study reach, directly linked to the flood regime, are expected to lead to a corresponding notable ecological dynamism throughout the parafluvial zone (Junk et al. 1989).

In contrast, a highly trained reach of the river Sense near Thörishaus, where $M$. germanica is absent, displayed drastically different behaviour from that of our study site (Gostner et al. 2013): indeed, even during low discharges, the channel bed is completely wetted, depositional forms are absent, and the spatial heterogeneity of the main hydraulic parameters is reduced (see also Montgomery and Buffington 1997). Moreover, an increase in flow discharge always involves significant variations in both the hydraulic depth and velocity, which indicates a permanent lack of temporal stability.

\section{Correlation between the observed natural stream dynamics and the presence of Myricaria germanica}

We found a consistent correlation between the distribution of $M$. germanica and the inundation frequency of the bars: gravel bars inundated by floods with a frequency greater than a 2-year return period are devoid of vegetation, particularly $M$. germanica. This absence is due to the low growth rates of the roots and of the plant in general during its first phases of life, which make it highly vulnerable to hydraulic disturbances (saplings are washed away). Instead, this species was observed growing on bars that are inundated every 4-5 years. In fact, as it reaches its second year of life, M. germanica becomes stronger and more resistant to both inundation and erosion/burial (Lener et al. 2013). During this phase, this species is notably successful in competition with other species, which is confirmed by the observation that the bars subject to this inundation frequency were populated almost exclusively by $M$. germanica. In contrast, $M$. germanica was not observed on islands subject to floods with a return period of approximately 20 years, whereas these formations were densely populated by species belonging to later stages of succession, e.g., Alnus incana, which are stronger competitors where periodic hydrologic disturbances are absent (Müller 2014). 
While focusing on the substrate characteristics, the bars populated by $M$. germanica are composed of gravel with a matrix of fine sand (that, from the volumetric sampling, amounts to circa $20 \%$ of the global material composition, even if several additional sand lenses were also identified on the bars). This condition is present only in highly heterogeneous physical environments and has been proven to constitute the ideal substrate for the germination of M. germanica (Benkler and Bregy 2010).

Concerning the spatial localization of the gravel bars populated by $M$. germanica, they are located near the main channels, where water depth fluctuations were minor during most of the year, thereby allowing the saplings to grow without facing notable hydraulic disturbances.

The analysis of sediment transport dynamics shows that erosion of the bars where $M$. germanica grows is initiated by floods with return periods of approximately 7 years. Further erosion leads to uprooting and then the complete removal of the plants. In terms of flow and flood pulses, it is confirmed that while the former are associated with changes in landscape heterogeneity due to water level fluctuations, major erosive floods can involve notable changes in landscape configuration, with a significant turnover of some of its elements (pioneer islands, woody debris) (Tockner et al. 2000).

\section{Implications}

\section{Advantages of numerical models for characterising stream hydro-morphological patterns}

The present research confirms that 2D hydrodynamic models can be a valuable support for quantitatively characterising the often complex hydro-morphological configuration of a river reach. In our context, their use proved to be essential for addressing the target questions.

First, the numerical modelling allowed us to analyse in detail the behaviour of the main hydraulic variables (e.g., water depth and flow velocity) throughout an extensive computational domain representing a $2-\mathrm{km}$ reach with an average bankfull width of $150 \mathrm{~m}$. An accurate analysis of an area this size would be difficult to perform by means of a classic field campaign. Nevertheless, we learned that two requirements for developing a precise model are an accurate topographic survey and a valid calibration phase.

A second, major advantage of the numerical modelling was the chance to simulate a broad range of flow discharges: indeed, the analysis spanned from low-flow conditions to a flood with a 50-year return period.

Finally, numerical models possess a predictive capability that is not achievable through field observation. They can simulate future morphologic and hydrologic modifications, thus constituting a unique tool, for example, in helping to assess the effectiveness of restoration strategies (e.g., Casas-Mulet et al. 2014; Gostner et al., submitted).

\section{Extrapolation of model results to other settings}

The present study provides quantitative support for deepening our knowledge of the complex interactions between the presence of $M$. germanica and the hydrologic regime. In particular, we observed a strong correlation between the presence of $M$. germanica and inundation frequency. The need of periodic floods is independent of the specific study site and therefore widely valid. Nevertheless, when considering the results in a more general context, other factors partially related to the characteristics of the analysed river and on the bioclimatic conditions of the area may also play a significant role.

First, at the study site $M$. germanica was found on gravel bars close to the water table. In contexts where other water sources are available (tributary water, soil water, upwelling groundwater) this species may colonise also areas further from the river channel (Tockner et al. 2000; Kudrnovsky 2013). Moreover, this pioneer riparian species requires sunny sites to grow, which are abundant in the study area; on the contrary, a prevalence of shady places would inhibit its colonisation (Michielon and Sitzia 2010). Then, in a broader perspective related to climatic and hydrological conditions, the timing of floods has been observed to play an important role for some biota dynamics (Junk et al. 1989). For example, it is problematic if the timing of inundations and the flowering and seed production phases are not properly synchronised, because the absence of sites with suitable moisture and nutrient content may inhibit $M$. germanica germination.

\section{Implications for river restoration}

This research confirms that riparian corridors are governed by a complex interplay between morphology, hydrology, solid transport and the riparian environment. A natural unaltered hydrologic and sedimentologic regime and the absence of artificial regulation works favour the development of suitable hydromorphological dynamics for the colonization of key early-succession riparian species such as M. germanica (Müller 2014). Therefore, effective and resilient restoration strategies should aim to recreate this equilibrium.

In particular, we demonstrated that the presence of $M$. germanica is strictly related to inundation frequency. Hence, when the natural regime along a river has been altered by the presence of hydropower plants, valuable actions could include the development of hydropower operation programmes aimed to recreate by means of artificially regulated floods the periodical inundation of the 
depositional forms in the downstream reaches and thereby improve riparian corridors. Moreover, longitudinal sediment connectivity should be promoted, to favour the maintenance of gravel bars and avoid the progressive riverbed degradation and bed forms loss.

\section{Future development of the research}

In the next steps of our research we intend to apply the analysis performed on river Sense to other study sites populated by $M$. germanica, located in various countries of the Alps. Indeed, monitoring the frequency of inundation of this pioneer species in many various river reaches and with different conditions would provide further validation of the present results. In addition to inundation frequency, the possible relevance of the inundation duration for the presence of $M$. germanica merits investigation. Special attention should also be given to the relationships between vegetation and sediment transport dynamics. This involves in particular the effects of plant roots on the strengthening of the soil and the consequent increase of the threshold for the initiation of sediment transport, together with the effects of roots on plant removal dynamics.

Acknowledgements This study was performed as part of the interdisciplinary research project "The integrated management of river systems", supported by the Swiss Federal Office for Environment (http://www.rivermanagement.ch), and as part of a research project co-financed by the Autonomous Province of Bolzano, South Tyrol (Italy). Moreover, we would like to thank the reviewers for helpful comments on the different stages of the manuscript.

\section{References}

Armanini A (2005) Principi di idraulica fluviale. Editoriale Bios.

Baptist MJ, Babovic V, Rodríguez Uthurburu J, Keijzer M, Uittenbogaard RE, Mynett A, Verwey A (2007) On inducing equations for vegetation resistance. J Hydraul Res 45(4):435-450

Beffa C (2004) 2D-Strömungssimulation mit FLUMEN. ÖWAV-Seminar "Fließgewässermodellierung - von der Ein- zur Mehrdimensionalität?". Wiener Mitteilungen. BOKU Wien

Benkler C, Bregy J (2010) Myricaria germanica: Experiments regarding seed germination and water stress. ETH Zürich und WSL Birmensdorf. http://www.wsl.ch/land/products/rhone-thur/ rivermanagement/pdf/BenklerBregy_SA10.pdf, p 45

Bertoldi W, Siviglia A, Tettamanti S, Toffolon M, Vetsch D, Francalanci S (2014) Modeling vegetation controls on fluvial morphological trajectories. Geophys Res Lett 41:7167-7175. doi:10.1002/2014GL061666

Bill HC, Spahn P, Reich M, Plachter H (1997) Bestandesveränderungen und Besiedlungsdynamik der Deutschen Tamariske, Myricaria germanica (L.) Desv., an der Oberen Isar (Bayern). Zeitschrift für Ökologie und Naturschutz 8:137-150

Bornette G, Tabacchi E, Hupp C, Puijalon S, Rostan JC (2008) A model of plant strategies in fluvial hydrosystems. Freshw Biol 53:1692-1705. doi:10.1111/j.1365-2427.2008.01994.x
Brownlie WR (1981) Compilation of alluvial channel data: laboratory and field. California Institute of Technology California, Report no. KH-R-43B.

Camporeale C, Ridolfi L (2006) Riparian vegetation distribution induced by river flow variability: A stochastic approach. Water Resourc Res 42(10):W10415. doi:10.1029/2006WR004933

Camporeale C, Perucca E, Ridolfi L, Gurnell AM (2013) Modeling the interactions between river morphodynamics and riparian vegetation. Rev Geophys 51:379-414. doi:10.1002/rog.20014

Casas-Mulet R, Alfredsen K, Killingtveit A (2014) Modelling of environmental flow options for optimal Atlantic salmon, Salmo salar, embryo survival during hydropeaking. Fish Manage Ecol 21:480-490

Chow VT (1959) Open-Channel Hydraulics. McGraw-Hill, New York

Corenblit D, Tabacchi E, Steiger J, Gurnell A (2007) Reciprocal interactions and adjustments between fluvial landforms and vegetation dynamics in river corridors : a review of complementary approaches. Earth Sci Rev 84:56-86

Crouzy B, Edmaier K, Pasquale N, Perona P (2013) Impact of floods on the statistical distribution of riverbed vegetation. Geomorphology 202:51-58

De Silva K, Tanaka N, Yagisawa J (2013) Return period of flood disturbance that increases diversity on gravel bars in middle stream of rivers. Landsc Ecol Eng. doi:10.1007/s11355-013-0229-4

Egger G, Angermann K, Gruber A (2010) Wiederansiedlung der Deutschen Tamariske (Myricaria germanica (L.) Desv.) in Kärnten. Karinthia II 200/120:393-418

Egger G, Politti E, Garofano-Gomez V, Blamauer B, Ferriere T, Rivaes R, Benjankar R, Habersack H (2013) Embodying interactions between riparian vegetation and fluvial hydraulic processes within a dynamic floodplain model: concepts and applications. In: Maddock I, Harby A, Kemp P, Wood P (eds) Ecohydraulics: an integrated approach. Wiley, Chichester, pp 407-427

Endress PK (1975) Verbreitungsrückgang von Myricaria germanica Desv. und Typha minima Hoppe auf der Alpennordseite Graubündens. Vierteljahrsschrift der Naturforschenden Gesellschaft in Zürich 120:1-14

EU WFD (2000) Establishing a framework for Community action in the field of water policy, Directive 2000/60/EC of the European Parliament and of the Council of 23 October 2000. The European Parliament and the Council of the European Union

FISRWG (1998) Stream corridor restoration: principles, processes, and practices. By the Federal Interagency Stream Restoration Working Group. GPO Item No. 0120-A. ISBN-0-934213-59-3

Friedman JM, Auble GT (1999) Mortality of riparian box elder from sediment mobilization and extended inundation. Regul Rivers Res Manage 15:463-476

Giller PS (2005) River restoration: seeking ecological standards. Editor's introduction. J Appl Ecol 42:201-207

Gonzalez E, Gonzalez-Sanchis M, Cabezas A, Comin FA, Muller E (2010) Recent changes in the riparian forest of a large regulated Mediterranean river: implications for management. Environ Manage 45:669-681

Gonzalez E, Gonzalez-Sanchis M, Comín FA, Muller E (2012) Hydrologic thresholds for riparian forest conservation in a regulated large Mediterranean river. River Res Appl 28(1):71-80. doi:10.1002/rra.1436

Gostner W (2012) The Hydro-Morphological Index of Diversity: a planning tool for river restoration projects. Communication 51 of the Laboratory of Hydraulic Constructions ( $\mathrm{LCH})$, Ecole polytechnique fédérale de Lausanne (EPFL), Ed. A. Schleiss, Lausanne

Gostner W, Parasiewicz P, Schleiss AJ (2013) A case study on spatial and temporal hydraulic variability in an alpine gravel-bed stream based on the hydromorphological index of diversity. Ecohydrology 6(4):652-667 
Gurnell AM, Bertoldi W, Corenblit D (2012) Changing river channels: the roles of hydrological processes, plants and pioneer fluvial landforms in humid temperate, mixed load, gravel bed rivers. Earth-Sci Rev 111(1-2):129-141

Hauer C, Unfer G, Graf W, Leitner P, Zeiringer B, Habersack H (2012) Hydro-morphologically related variance in benthic drift and its importance for numerical habitat modelling. Hydrobiologia 683(1):83-108

Jansson R, Nilsson C, Dynesius M, Andersson E (2000a) Effects of river regulation on river-margin vegetation: A comparison of eight boreal rivers. Ecol Appl 10:203-224

Jansson R, Nilsson C, Renofalt B (2000b) Fragmentation of riparian floras in rivers with multiple dams. Ecology 81:899-903

Junk WJ, Bayley PB, Sparks RE (1989) The flood pulse concept in river-floodplain systems. Can Spec Publ Fish Aquat Sci 106:110-127

Kellerhals R, Neill CR, Bray DI (1972) Hydraulic and geomorphic characteristics of rivers in Alberta. Alberta Research Council, Edmonton, Alberta, p 52

Kudrnovsky H (2013) Alpine rivers and their ligneous vegetation with Myricaria germanica and riverine landscape diversity in the Eastern Alps: proposing the Isel river system for the Natura 2000 network. eco.mont Journal on Protected Mountain Areas. Res Manag 5:5-18

Kudrnovsky H, Stöhr O. (2013) Myricaria germanica (L.) Desv - historisch und aktuell in Österreich: Ein dramatischer Rückgang einer Indikatorart von europäischem Interesse. Stapfia 99:13-34

Lanz T, Stecher R (2009) Untersuchungen zur Samenproduktion und -ausbreitung einer Kleinpopulation von Myricaria germanica an der Sense. IKAÖ Bern und WSL Birmensdorf. http://www.wsl. ch/land/products/rhone-thur/rivermanagement/pdf/LanzStecher_ PA2009.pdf, p 91. Accessed 18 Jan 2017

Lener VFP, Egger G, Karrer G (2013) Sprossaufbau und Entwicklung der Deutschen Tamariske (Myricaria germanica) an der Oberen Drau (Kärnten, Österreich). Karinthia II 203/123:515-552

Lorang MS, Hauer FR (2006) Fluvial geomorphic processes. In: Hauer FR, Lamberti GA (eds) Methods in stream ecology, 2nd edn. Elsevier Academic, San Diego, 877 pp

Michielon B, Sitzia T (2010) Presenza di Myricaria germanica (L.) Desv. lungo il torrente Avisio (Trentino, Italia Settentrionale). Annali Museo Civico Rovereto 26:319-346

Montgomery DR, Buffington JM (1997) Channel-reach morphology in mountain drainage basins. Geol Soc Am Bull 109:596-611

Müller N (2014) Wasserkraftanlagen und FFH-Lebensräume "Alpine Flüsse" unter besonderer Berücksichtigung der Deutschen Tamariske in Tirol. Naturschutzpublikationen Tirol. http://www.tirol. gv.at/umwelt/naturschutz/publikationen. Accessed 18 Jan 2017

Nepf H (2012a) Flow and transport in regions with aquatic vegetation. Annu Rev Fluid Mech 44:123-142

Nepf H (2012b) Hydrodynamics of vegetated channels. J Hydraul Res 50(3):262-279

Nilsson C, Jansson R (1995) Floristic differences between riparian corridors of regulated and free-flowing boreal rivers. Regul Rivers Res Manag 11:55-66

Nilsson C, Svedmark M (2002) Basic principles and ecological consequences of changing water regimes: riparian plant communities. Environ Manage 30(4):468-480

Palmer MA, Bernhardt ES, Allan JD, Lake PS, Alexander G, Brooks S, Carr J, Clayton S, Dahm CN, Follstad Shah J, Galat DL, Loss SG, Goodwin P, Hart DD, Hassett B, Jenkinson R, Kondolf GM, Lave R, Meyer JL, O’Donnell TK, Pagano L, Sudduth E (2005) Standards for ecologically successful river restoration. J Appl Ecol 42:208-217

Pasquale N, Perona P, Francis R, Burlando P (2012) Effects of streamflow variability on the vertical root density distribution of willow cutting experiments. Ecol Eng 40:167172. doi:10.1016/j.ecoleng.2011.12.002

Pezeshki SR, Shields FD (2006) Black willow cutting survival in streambank plantings, Southeastern United States. J Am Water Resourc Assoc 42(1):191-200

Pfaundler M, Zappa M (2006) Die mittleren Abflüsse über die ganze Schweiz Ein optimierter Datensatz im $500 \times 500$ m Raster. Wasser Energie Luft Heft 4/2006:291-298

Poff NL, Allan JD, Bain MB, Karr JR, Prestegaard KL, Richter BD, Sparks RE, Stromberg JC (1997) The natural flow regime: a paradigm for river conservation and management. Bioscience 47:769-784

Pollen-Bankhead N and Simon A (2005) Estimating the mechanical effects of riparian vegetation on stream bank stability using a fiber bundle model. Water Resourc Res. doi:10.1029/2004WR003801

Pollen-Bankhead N, Simon A (2010) Hydrologic and hydraulic effects of riparian root networks on streambank stability: Is mechanical root-reinforcement the whole story? Geomorphology 116(3):353-362. doi:10.1016/j.geomorph.2009.11.013

Pringle CM, Naiman RJ, Bretschko G, Karr JR, Oswood MW, Webster JR, Welcomme RL, Winterbourn MJ (1988) Patch dynamics in lotic systems: the stream as a mosaic. J North Am Benthol Soc 7(4):503-524

Robinson CT, Uehlinger U (2003) Using artificial floods for restoring river integrity. Aquat Sci 65:181-182

Rohde S, Kienast F, Bürgi M (2004) Assessing the restoration success of river widenings: a landscape approach. Environ Manage 34:574-589

Roni P, Beechie TJ, Bilby RE, Leonetti FE, Pollock MM, Pess GR (2002) A review of stream restoration techniques and a hierarchical strategy for prioritizing restoration in Pacific Northwest watersheds. North Am J Fish Manag 22:1-20

Sadler JP, Bell D, Fowles A (2004) The hydroecological controls and conservation value of beetles on exposed riverine sediments in England and Wales. Biol Conserv 118:41-56

Schropp MHI, Bakker C (1998) Secondary channels as a basis for the ecological rehabilitation of Dutch rivers. Aquat Conserv Mar Freshw Ecosyst 8:53-59

Simonson DS, Lyons J, Kanehl PD (1994) Quantifying fish habitat in streams: transect spacing, sample size, and a proposed framework. North Am J Fish Manag 14(3):607-615

Solari L, Van Oorschot M, Belletti B, Hendriks D, Rinaldi M, Vargas-Luna A (2015) Advances on modelling riparian vegetationhydromorphology interactions. River Res Applic 32:164-178. doi:10.1002/rra.2910.

Stanford JA, Lorang MS, Hauer FR (2005) The shifting habitat mosaic of river ecosystems. Verhandlungen der internationalen Vereinigung für theoretische und angewandte Limnologie 29:126-136

Strickler A (1923) Beiträge zur Frage der Geschwindigkeitsformel und der Rauhigkeitszahlen für Ströme, Kanäle und geschlossene Leitungen. Mitteilungen des Bundesamtes für Wasserwirtschaft, Nr. 16, Bern, 113 pp

Tanaka N, Yagisawa J (2012) Index of medium-class flood disturbance for increasing diversity of vegetation area at gravel bars or islands in middle of rivers. Int J River Basin Manag 10:255-267

Tockner K, Schiemer F (1998) Conservation by restoration: the management concept for a river-floodplain system on the Danube River in Austria. Aquat Conserv Mar Freshw Ecosyst 8:71-86

Tockner K, Stanford JA (2002) Riverine floodplains: present state and future trends. Environ Conserv 29:308-330

Tockner K, Malard F, Ward JV (2000) An extension of the flood pulse concept. Hydrol Process 14:2861-2883. doi:10.1002/10991085(200011/12)14:16/17<2861::AID-HYP124>3.0.CO;2-F 
Turnipseed DP, Sauer VB (2010) Discharge measurements at gaging stations. U.S. Geological Survey Techniques and Methods book 3, chap. A8, 87 p. (also available at http://pubs.usgs.gov/ $\mathrm{tm} / \mathrm{tm} 3-\mathrm{a} 8 /$.

Werth S, Scheidegger C (2014) Gene flow within and between catchments in the threatened riparian plant Myricaria germanica. PLoS One 9:e99400. doi:10.1371/journal.pone.0099400

Werth S, Schödl M, Scheidegger C (2014) Dams and canyons disrupt gene flow among populations of a threatened riparian plant. Freshw Biol 59:2502-2515. doi:10.1111/fwb.12449
Wolman MG (1954) A method of sampling coarse bed material. Am Geophys Union Trans 35:951-956

Yalin MS (1972) Mechanics of sediment transport. 1st and 2nd edn. Pergamon, New York

Ye F, Chen Q, Blanckaert K, Ma J (2013) Riparian vegetation dynamics: insight provided by a process-based model, a statistical model and field data. Ecohydrol 6(4):567-585 